\title{
Role of infection in the Guillain-Barré syndrome
}

\author{
S. C. MELNICK ${ }^{1}$ AND T. H. FLEWETT \\ From the Regional Virus Laboratory, East Birmingham Hospital, and the University Department of Medicine, \\ Queen Elizabeth Hospital, Birmingham
}

There are two main hypotheses concerning the aetiology of the Guillain-Barré syndrome. First, that it is a primary virus infection, and, secondly, that it is a form of 'neuro-allergy' (Furtado, 1950) with the allergic state resulting from either an antecedent illness (usually a virus disease) or an immunizing injection. The terms 'acute infectious polyneuritis' and 'acute post-infective polyneuritis' exemplify these two contrasting views. This paper reports the results of experiments designed to identify a specific virus and also to present fresh evidence concerning the importance of antecedent infections. Special attention is given to infections of the respiratory tract.

As there is no other agreed title which adequately covers the clinical and aetiological features of this condition, the eponymous term 'Guillain-Barré syndrome' will continue to be used to describe the cases reported here.

\section{PATIENTS}

Fifty-two are included in this study. Most of them have been questioned and examined by one of us (S.C.M.) at an early stage of their illness, and their progress assessed for periods up to three years. The diagnostic criteria used were laid down by Guillain, Barré, and Strohl (1916) and re-emphasized by Osler and Sidell (1960), and were fulfilled by most of our patients. These criteria comprised an acute or subacute symmetrical paralysis of all four limbs with hypotonia, and cranial nerve involvement in some cases; sensory disturbance was usually only of moderate degree, the deep reflexes were absent, and the superficial reflexes remained intact. Among the standard laboratory investigations the only relevant abnormality was that the cerebrospinal fluid showed a rise in the protein content ( $>50 \mathrm{mg} . / 100 \mathrm{ml}$.), but routine chemistry and cytology were otherwise normal.

A few cases, however, did not fulfil all these criteria: the cerebrospinal fluid protein was normal in 10 , and one case had a moderate transient increase in the lymphocyte count in the cerebrospinal fluid; in some cases the sensory disturbance was more severe and (in one case only) the reflexes were intact. Further clinical and immunological evidence to justify their inclusion, and also supporting

\footnotetext{
${ }^{1}$ Present address: Dudley Road Hospital, Birmingham 18.
}

the conclusions of Haymaker and Kernohan (1949), will be reported elsewhere.

METHODS

EVIDENCE OF A PRIMARY VIRAL AETIOLOGY All 52 patients were questioned as to whether they had been in contact with other cases of paralytic illness. The geographic distribution of cases was mapped to ascertain whether or not the cases occurred in groups within small circumscribed areas. The patients were also questioned specifically as to contact with sick animals, particularly cats, in the weeks before the neurological illness, in view of the report of such an association by Campbell (1958).

Virus isolation studies Specimens of faeces and cerebrospinal fluid and also throat swabs from many of the cases were obtained as early as possible and inoculated into at least two types of tissue culture prepared from either rhesus monkey kidney, HeLa type cells, human embryo kidney, or human embryo lung fibroblasts; a few specimens were also inoculated into newborn kitten kidney cultures. In addition many of the specimens were inoculated by intracerebral and subcutaneous routes into suckling mice within 48 hours of birth.

Serological evidence of a virus infection depended upon the presence of complement-fixing antibodies to the virus antigens listed in Table VIb. With two exceptions, from whom specimens were only obtained on one occasion, sera were collected from each patient on at least two occasions and in as many cases as possible the interval between these collections was seven to 10 days. The complement-fixation test was performed in the conventional manner employed in most routine virus laboratories, using perspex trays. Three minimal haemolytic doses of guineapig complement and an indicator system of $2 \%$ sensitized sheep cells were used. Doubling dilutions of patients' sera from $1: 4$ to $1: 128$ were initially incubated overnight at $4^{\circ} \mathrm{C}$. in the presence of the guinea-pig complement and $50 \%$ haemolysis was regarded as the titration end-point. A positive complement-fixation test with a titre of $1: 16$ or over was taken to be evidence of a fairly recent infection, and a four-fold rise in titre from 'acute' to 'convalescent' phase sera, with a subsequent fall in titre if further specimens were examined, suggested that the infection was very recent. It is recognized, however, that in an isolated case a titre of $1: 16$ is suggestive, but not proof positive, of recent infection, but assumes greater significance in the context of an epidemic, e.g., of influenza (Stuart-Harris, 1953; Grist, Kerr, and Isaacs, 1961), although there are 
certain exceptions, particularly in the case of antibodies to Psittacosis group antigen and Coxiella burneti $(\mathrm{Q}$ fever) where high titres may persist for many months. Flewett (1963) demonstrated the presence of antibodies to influenza $A$ to a titre of $1: 16$ or over in certain epidemics in an appreciable number of the population, and sera reported here containing antibodies to influenza $\mathbf{A}$ and $B$ were collected at a time when there were epidemics caused by these viruses.

EVIDENCE OF ASSOCIATION WITH ANTECEDENT INFECTION All patients were asked whether they had had any infection, particularly of the respiratory tract, in the three months before the onset of the neurological illness. They were also questioned about recent inoculations, or any other recent events which they or the examiner considered could have been relevant. The time between the first day of antecedent illness and the onset of the Guillain-Barré syndrome was noted and was regarded as the 'latent period'.

The incidence of recent respiratory tract infections among patients with the Guillain-Barre syndrome was compared with the incidence in the general population at risk at the same time. The trial was conducted in two parts. In the first (trial 1), a group of 21 cases was compared with a random group of patients who had been admitted to medical wards for treatment of any acute condition other than peripheral or central nervous demyelinating disease. The second group of patients was more carefully controlled (trial 2), for each case of the Guillain-Barré syndrome was matched by age and sex with a control drawn from normal healthy hospital staff and from patients who had been admitted with any condition other than respiratory or demyelinating diseases. Both control groups were questioned as to whether or not they had had a respiratory infection in the previous three months and the interval from the first day of such an infection until the time of questioning was also noted.

Objective evidence of antecedent virus infection was based on the presence of antibodies in the serum to the viruses listed in Table VI. The sera were obtained at as early' a stage as possible in the evolution of the neurological syndrome. If antibody to a titre of $1: 16$ or over to one of the viruses tested was found in the first 14 days of the neurological illness, with a fall in titre in subsequent sera, this was considered to be reasonable evidence that such a virus had caused a clinical or subclinical infection within the previous one month. In a few of the cases sera, which were not obtained until more than 10 days after the onset of the peripheral neuritis, contained virus antibodies. These antibodies were accepted as indicating the probable nature of the recent antecedent infection provided that there was a history consistent with such an infection. Positive viral serology in these subjects coincided with clinical and serological evidence of epidemics in the general population caused by the relevant viruses.

INTERCURRENT INFECTIONS A special note was made of any infectious disease occurring after the onset of the peripheral neuritis, and the possible effect assessed clinically, of such an additional illness on the peripheral neuritis. In addition studies of sera taken during both the acute and recovery stages of the syndrome provided the opportunity to assess objectively the incidence of certain specific intercurrent virus infections in this series of cases.

\section{RESULTS}

EPIDEMIOLOGY There was no evidence in this group of cases to suggest that the disease could be trans- or mitted from one patient to another. A noteworthe case was that of a 10-year-old boy, one of monot o zygous twins, who suffered from the Guillain-Barres syndrome and made a satisfactory recovery. As long $\vec{\theta}$ as two and a half years later his twin brother had not suffered from this disease.

Although many of the patients had pets, in ne case was there any obvious relationship between the neurological illness and illness in their pets. Int particular, no patient admitted to being in contact with a cat which might have been suffering from feline enteritis or feline pneumonitis.

The monthly incidence for cases studied between November 1959 and October 1962 is given in Table II. This shows that in 32 cases the illness began between January and June and in 11 cases between

TABLE I

MONTHLY INCIDENCE OF GUILLAIN-BARRÉ SYNDROME

\begin{tabular}{|c|c|c|c|c|c|c|c|c|c|c|c|c|c|c|}
\hline & \multicolumn{13}{|c|}{ Month } \\
\hline & & oct. & Nov. & Dec. & Jan. & $F e b$. & Mar. & Apr. & May & June & July & Aug. & Sept. & \\
\hline & $1959-60$ & 1 & 0 & 1 & 2 & 6 & 1 & 1 & 2 & 2 & 2 & 1 & 1 & \\
\hline & $1960-61$ & 1 & 0 & 0 & 2 & 3 & 0 & 0 & 2 & 3 & 2 & 1 & 0 & \\
\hline & $1961-62$ & 0 & 0 & 1 & 1 & 0 & 3 & 1 & 1 & 2 & 0 & 0 & $\mathbf{0}$ & \\
\hline & Total & 2 & 0 & 2 & 5 & 9 & 4 & 2 & 5 & 7 & 4 & 2 & 1 & 43 \\
\hline $\begin{array}{l}\text { Bimonthly } \\
\text { incidence }\end{array}$ & $\left\{\begin{array}{l}\text { Analysis } \\
\text { Expected } \\
\text { Observed }\end{array}\right.$ & & 2 & & 7 & & 13 & $7 \cdot 17$ & 7 & & 11 & & 3 & $\begin{array}{l}\mathrm{n}=5, x^{2}=13.05 \\
\mathrm{p}=>0.01<0.05\end{array}$ \\
\hline
\end{tabular}


July and December. The difference in numbers between these two groups appears to be significant and suggests a predilection for the cooler months of the year. There were two main peaks of incidence, in February and June respectively, and Table I further summarizes the data in order to assess the significance of bimonthly differences in the incidence of the Guillain-Barre syndrome for the years 1959-62. The result of this analysis, also given in Table I, suggests that the two main peaks of incidenceJanuary-February (nine cases) and May-June (seven cases)-are probably significant, although the number of cases (43) is rather small for an analysis of this type.

EVIDENCE OF A SPECIFIC VIRUS INFECTION Table II shows the nature and number of specimens examined for such evidence. Only two of the patients yielded positive results, in both cases Coxsackie B5 viruses. One of the isolations was made from the cerebrospinal fluid in HeLa type tissue cultures and in the second case from throat washings in newborn suckling mice. At that time Coxsackie B5 infections were prevalent throughout central and southern England. The cerebrospinal fluid from which the virus was isolated showed a moderate lymphocytosis, but this patient's sensory and motor neuropathy resembled that seen in most of our other cases of the GuillainBarré syndrome and later samples of the cerebrospinal fluid were normal. (This may, however, be an example of double pathology.)

There was no consistent serological evidence of antibodies to any particular one of the virus antigens studied. No virus was isolated in the kitten kidney cultures.

ANTECEDENT ILLNESSES Thirty-six of our 52 patients had such illnesses. which are detailed in Table III, together with the latent periods between the respective illnesses and first neurological symptoms. With one exception (L.T. with insect bites), all had had some recent infection, and those affecting the upper respiratory tract predominated (26 cases). In one subject (D.P.) the infection was iatrogenic (vaccination against smallpox).
TABLE III

ANTECEDENT ILLNESS IN THE LATENT PERIOD IN 36 PATIENTS

\begin{tabular}{|c|c|c|c|c|c|}
\hline $\begin{array}{l}\text { Antecedent } \\
\text { Illness }\end{array}$ & Patient & $\begin{array}{l}\text { Latent } \\
\text { Period } \\
\text { (days) }\end{array}$ & $\begin{array}{l}\text { Antecedent } \\
\text { Illness }\end{array}$ & Patient & $\begin{array}{l}\text { Latent } \\
\text { Period } \\
\text { (days) }\end{array}$ \\
\hline $\begin{array}{l}\text { Respiratory } \\
\text { illness } \\
\text { (26 patients) }\end{array}$ & $\begin{array}{l}\text { A.B. } \\
\text { F.T. } \\
\text { G.M. } \\
\text { C.W. } \\
\text { G.C. } \\
\text { D.P. } \\
\text { E.C. } \\
\text { R.H. } \\
\text { A.T. } \\
\text { D.J. } \\
\text { S.R. } \\
\text { E.A. } \\
\text { S.C. } \\
\text { K.C. } \\
\text { M.L. } \\
\text { L.L. } \\
\text { S.M. }\end{array}$ & $\begin{array}{r}0 \\
0 \\
1 \\
2 \\
4 \\
6 \\
7 \\
7 \\
7 \\
12 \\
12 \\
14 \\
14 \\
14 \\
14 \\
14 \\
14\end{array}$ & $\begin{array}{l}\text { Chickenpox } \\
\text { Mumps } \\
\begin{array}{l}\text { Impetigo } \\
\text { Rash ?cause }\end{array} \\
\begin{array}{l}\text { Pyrexia of } \\
\text { uncertain } \\
\text { origin }\end{array} \\
\left.\begin{array}{l}\text { Vaccination } \\
\text { Insect bites } \\
\begin{array}{l}\text { Retention } \\
\text { of urine } \\
\text { Prostatec- } \\
\text { tomy }\end{array}\end{array}\right\}\end{array}$ & $\begin{array}{l}\text { S.H. } \\
\text { D.G. } \\
\text { J.R. } \\
\text { E.M. } \\
\text { F.M. } \\
\text { J.P. } \\
\text { S.C. } \\
\text { S.R. } \\
\text { M.L. } \\
\text { S.M.1 }\end{array}$ & $\begin{array}{r}2 \\
14 \\
42 \\
\\
7 \\
28 \\
7 \\
72 \\
42 \\
21 \\
21\end{array}$ \\
\hline
\end{tabular}

${ }^{1}$ Also had respiratory illness

\section{TABLE IV}

SIGNIFICANCE OF LATENT PERIOD BETWEEN RESPIRATORY INFECTION AND ONSET OF GUILLAIN-BARRÉ SYNDROME Guillain-Barré Syndrome

\begin{tabular}{|c|c|c|c|}
\hline No. of Cases & $\begin{array}{l}\text { Latent Period } \\
\text { (days) }\end{array}$ & No. of Cases & $\begin{array}{l}\text { Latent Period } \\
\text { (days) }\end{array}$ \\
\hline 2 & 0 & 1 & 1 \\
\hline$\overline{1}$ & 1 & 4 & 7 \\
\hline 1 & 2 & 5 & 14 \\
\hline 1 & 4 & 2 & 21 \\
\hline 1 & 6 & 1 & 28 \\
\hline 3 & 7 & 1 & 42 \\
\hline 2 & 12 & $i$ & 49 \\
\hline 10 & 14 & 2 & 56 \\
\hline 1 & 16 & 2 & 62 \\
\hline 2 & 21 & & \\
\hline 1 & 63 & & \\
\hline $\begin{array}{c}\text { Total cases } \\
2 j^{2}\end{array}$ & $\begin{array}{c}\text { Mean Time } \\
12 \cdot 8\end{array}$ & $\begin{array}{c}\text { Total Cases }^{1} \\
19\end{array}$ & $\begin{array}{c}\text { Mean Time } \\
26 \cdot 1\end{array}$ \\
\hline
\end{tabular}

${ }^{1}$ Information not available from four patients One subject (G.H., Table III) excluded 
It was only feasible in the case of respiratory infections to assess the significance of duration of the latent period. Analysis of these data (Table IV) confirms that this is shorter and less variable than in the control group, as the respective mean durations of $12 \cdot 8$ and $26 \cdot 1$ days are significantly different (S.E. $=$ $4.87, \mathrm{n}=42, \mathrm{t}=2 \cdot 7, \mathrm{p}=<0.01$ ). In the case of other antecedent illnesses, however, Table III shows a wide variation of latent periods, ranging from two to 42 days.

The incidence of these respiratory infections has been compared with their incidence in control populations. The method of conducting these trials has been described above, and in Table $\mathrm{V}$ their results have been analysed both separately and together. Initially (part 1 of Table V) a three-month latent period had been selected as the longest interval that could possibly be significant, as in one of our first cases (D.S., Table III) the respiratory infection occurred nine weeks before the onset of neurological symptoms. On this basis the incidence of antecedent respiratory infection in the Guillain-Barré syndrome was not statistically significantly different from the control group.

Two of the subjects in this control group were actually admitted specifically for treatment of respiratory infections (pneumonia in both cases), but, even if these are excluded from the analysis, the incidence of such infections is still not statistically different between the two groups $\left(\chi^{2}=2 \cdot 45, n=1\right.$, $\mathrm{p}=>0 \cdot 1<0 \cdot 2)$.

Subsequently, however, it became clear that the only case in which the latent period was longer than three weeks was the patient D.S. referred to above. Therefore, in Table V, part 2, the results are summarized of a further analysis which was designed to assess the frequency with which respiratory infection occurred within a latent period of four weeks. These results show clearly that within this time interval $\underset{\mathbb{}}{Z}$ respiratory infections occurred much more frequently before the Guillain-Barré syndrome than in the control population.

Serological evidence of a virus disease immediately 0 preceding the Guillain-Barré syndrome is summarized in Table VIa. and given in detail in Table VIb (Criteria for such evidence have been given above.) $\stackrel{\overrightarrow{0}}{\overrightarrow{7}}$ Comparative data are given for 1,817 other subjects.whose 'acute phase' sera were screened for viral $\overrightarrow{\vec{F}}$ antibodies in the same period. The number of sub- $-\overrightarrow{0}$ jects from whom sera were obtained within 10 days $\frac{C}{0}$ of the neurological illness (or later where the sero- $\overline{\bar{c}}$ logical findings corresponded well with the clinical $\widehat{\nabla}$ history of antecedent infection) was twenty-nine. $\frac{2}{v}$ Table VIa shows a high incidence of positive virus $\$$ complement-fixation tests in the cases of peripheral $\overrightarrow{0}$ neuritis $(14 / 29,48 \%)$. This incidence is significantly $\overrightarrow{\vec{H}}$ greater than in the miscellaneous group, in which the $\vec{\sigma}$ incidence of positive virus complement-fixation tests was $30 \%\left(\chi^{2}=4.5, \mathrm{n}=1, \mathrm{p}=>0.02<0.05\right)$. Analysis of the data for serological evidence of the individual viruses studied, however, revealed a sig- $v$ nificantly high incidence for the Guillain-Barré syp drome only for glandular fever $\left(\chi^{2}=55 \cdot 2, \mathrm{n}=\right.$ \& $\mathrm{p}=<0.001)$, and psittacosis $\left(\chi^{2}=25 \cdot 7, \mathrm{n}=\stackrel{\mathbb{Q}}{\mathrm{P}}\right.$ 음 $\mathrm{p}=<0.001)$. It should be particularly noted that the incidence of influenza $\mathbf{A}$ infection was not sie nificantly higher than in the control group $\left(\chi^{2}\right.$ \& $\frac{0}{0}$ $0.58, \mathrm{n}=1, \mathrm{p}=>0 \cdot 1<0.5)$. Quite clearly also the was no significant difference in incidence betwee्f the two groups in the case of influenza B, para

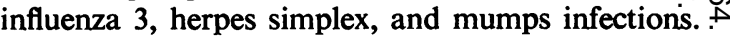
In our peripheral neuritis group the association with parainfluenza $2(3 / 29)$ and parainfluenza $3(1 / 29)$ infections is obviously greater than in the control

TABLE V

SIGNIFICANCE OF ANTECEDENT RESPIRATORY INFECTIONS IN THE GUILLAIN-BARRÉ SYNDROME

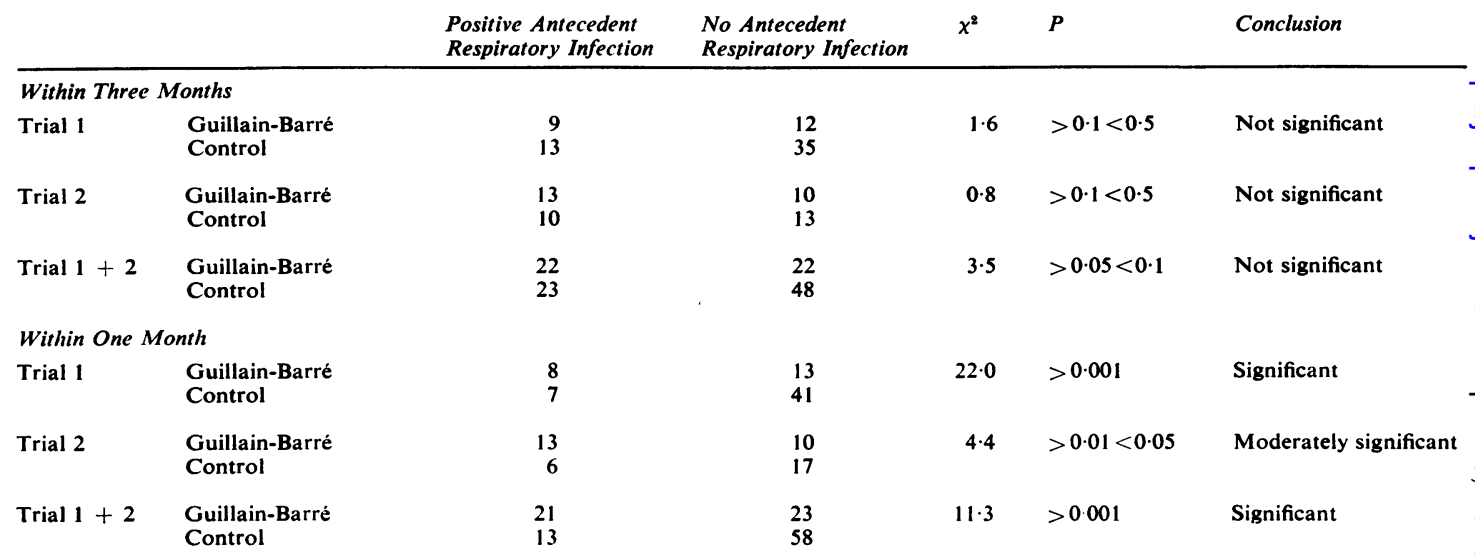


TABLE VIa

SUMMARY OF SEROLOGICAL EVIDENCE OF ANTECEDENT VIRUS INFECTIONS IN GUILLAIN-BARRÉ SYNDROME

Viral Antigen

\begin{tabular}{|c|c|c|c|}
\hline & \multirow{2}{*}{$\begin{array}{l}\text { Guillain-Barré } \\
\text { Syndrome } \\
\text { (29 Subjects) }\end{array}$} & \multicolumn{2}{|c|}{$\begin{array}{l}\text { Control Group } \\
\text { Routine Viral Studies }\end{array}$} \\
\hline & & No. Positive & No. Tested \\
\hline $\begin{array}{l}\text { Influenza A } \\
\text { Influenza B } \\
\text { Influenza C }\end{array}$ & $\begin{array}{l}4\left(2^{2}\right) \\
2\left(1^{2}\right) \\
0\end{array}$ & $\begin{array}{r}177 \\
62 \\
81\end{array}$ & $\begin{array}{l}1,817 \\
1,817 \\
1,817\end{array}$ \\
\hline $\begin{array}{l}\text { Parainfluenza } 1 \\
\text { Parainfluenza } 2 \\
\text { Parainfluenza } 3\end{array}$ & $\begin{array}{l}\mathbf{0} \\
\mathbf{3} \\
\mathbf{1}\end{array}$ & $\begin{array}{r}4 \\
6 \\
73\end{array}$ & $\begin{array}{l}1,817 \\
1,144 \\
1,749\end{array}$ \\
\hline Herpes simplex & 1 & 9 & 1,445 \\
\hline $\begin{array}{l}\text { Mumps viral } \\
\text { Mumps soluble }\end{array}$ & $\begin{array}{l}1 \\
0\end{array}$ & $\begin{array}{l}45 \\
16\end{array}$ & $\begin{array}{l}1,817 \\
1,817\end{array}$ \\
\hline Psittacosis & 4 & 31 & 1,817 \\
\hline Adenovirus & 1 & 75 & 1,817 \\
\hline Paul Bunnell & 3 & 7 & 1,817 \\
\hline $\begin{array}{l}\text { Poliomyelitis I } \\
\text { Poliomyelitis II } \\
\text { Poliomyelitis III }\end{array}$ & $\begin{array}{l}0 \\
0 \\
1\end{array}$ & $\begin{array}{l}7 \\
2 \\
9\end{array}$ & $\begin{array}{l}1,817 \\
1,817 \\
1,817\end{array}$ \\
\hline Q Fever & $\mathbf{0}$ & 3 & 1,789 \\
\hline Coe & $\mathbf{0}$ & 2 & 1,817 \\
\hline $\begin{array}{l}\text { Proportion of } \\
\text { subjects positive }\end{array}$ & $14 / 29(48 \%)$ & $543 / 1,817$ & $(30 \%)$ \\
\hline
\end{tabular}

TABLE VII a

SUMMARY OF SEROLOGICAL EVIDENCE OF INTERCURRENT VIRUS INFECTIONS IN GUILLAIN-BARRÉ SYNDROME
Viral Antigen
No. of Subjects with
Positive Serology 1

Influenza A
Influenza B
Influenza C
Parainfluenza 1
Parainfluenza 2
Adenovirus
Mumps viral
Mumps soluble
Poliomyelitis I
Poliomyelitis III
Herpes simplex
Proportion of
subjects affected

1
1
3
1
1
1
2
1
1
1
12

$16 / 52(31 \%)$

IIncludes all 52 patients studied

group, but the small number of positive results recorded makes statistical analysis impossible.

Clinically overt intercurrent infections were not commonly encountered in the hospital patients studied, except for pulmonary complications which occurred in seven of the patients who required tracheostomy. There was, however, serological evidence of intercurrent infections. As shown in Tables VIIa and VIIb there was a high incidence of serologically proven herpes simplex infection (12 cases) and also occasional cases of influenza A, B, and $C$, parainfluenza 1 and 2 , adenovirus, mumps, and poliomyelitis (types I and III). The clinical picture in the three cases whose sera contained antibodies to poliomyelitis viruses was typical of an acute sensorimotor neuropathy and quite unlike poliomyelitis itself.

\section{DISCUSSION}

These results fail to support the theory that the Guillain-Barré syndrome is a primary virus disease, although Guillain (1953) himself has continued to favour this theory. Evidence of an ultrafilterable agent in the spinal cord of a patient with an ascending paralysis was reported by Leschke (1914), and Pappenheimer, Bailey, Cheever, and Daniels (1951) reported isolations from specimens of faeces from a child suffering from polyneuritis. Both reports were based on the results of monkey inoculation experiments. The only other report of positive virus isolation studies which implied a direct aetiological relationship to the Guillain-Barré syndrome was that of Bergamasco and Longhi (1949) who claimed to have isolated a virus from the serum and cerebrospinal fluid of a patient by inoculation into white mice. In contrast, Parker, Wilt, Dawson, and Stackiw (1960), who reported the isolation of an adenovirus in tissue culture from the cerebrospinal fluid of one patient with the Guillain-Barré syndrome, and Gear, Measroch, and Prinsloo (1956) and Jackson (1961), who both reported the isolation of Coxsackie A virus from some of their cases, did not claim that these viruses directly attacked the neurones, but considered their action to be indirect, e.g., by some hypothetical effect on the peripheral nerve 'supporting' tissues. In an account of a post-herpes zoster Guillain-Barré syndrome, Knox, Levy, and Simpson (1961) reported the isolation of an ECHO 9 virus in the cerebrospinal fluid of one patient. The significance of this finding also remains in doubt. Negative results have been reported by Lassen, Ipsen, and Bang (1943) and by Haymaker and Kernohan (1949) on the basis of further animal inoculation experiments.

Despite the difference of opinion in the literature concerning their significance, there is no doubt that a certain small proportion of cases of the GuillainBarré syndrome do have concurrent virus infections. The difficulty is in the interpretation to be given to the presence of these viruses. First, the diversity of viruses isolated is at complete variance with the concept of a specific viral aetiology, and, secondly, our isolation of Coxsackie B5 virus from two patients 
TABLE VIb

SEROLOGICAL EVIDENCE (COMPLEMENT-FIXING ANTIBODIES) OF ANTECEDENT VIRUS INFECTION IN GUILLAIN-BARRÉ SYNDROME IN 14 OF 29 CASES

\begin{tabular}{|c|c|c|c|c|c|c|c|c|}
\hline \multirow{3}{*}{$\begin{array}{l}\text { Case } \\
\text { No. }\end{array}$} & \multirow[t]{3}{*}{ Name } & \multirow[t]{3}{*}{ Sex } & \multirow{3}{*}{$\begin{array}{l}\text { Age } \\
\text { (yr.) }\end{array}$} & \multirow{3}{*}{$\begin{array}{l}\text { Nature of } \\
\text { Initial Illness }\end{array}$} & \multirow{3}{*}{$\begin{array}{l}\text { Latent } \\
\text { Period } \\
\text { (days) }\end{array}$} & \multicolumn{3}{|c|}{ First Serum } \\
\hline & & & & & & \multicolumn{2}{|c|}{ Interval (days) From } & \multirow{2}{*}{$\begin{array}{l}\text { Complemen } \\
\text { Titre }\end{array}$} \\
\hline & & & & & & $\begin{array}{l}\text { Initial } \\
\text { Illness }\end{array}$ & $\begin{array}{l}\text { Onset of } \\
\text { Guillain- } \\
\text { Barré } \\
\text { Syndrome }\end{array}$ & \\
\hline 1 & G.M. & $\mathbf{M}$ & 59 & $\begin{array}{l}\text { Head cold, sore } \\
\text { throat }\end{array}$ & 1 & 3 & 2 & $\begin{array}{r}\text { Influenza A } \\
1: 16 \\
\text { Influenza } \mathrm{B} \\
1: 16\end{array}$ \\
\hline
\end{tabular}

\begin{tabular}{|c|c|c|}
\hline \multicolumn{2}{|c|}{ Interval (days) From } & Complement-fïing \\
\hline $\begin{array}{l}\text { Initial } \\
\text { Illness }\end{array}$ & $\begin{array}{l}\text { Onset of } \\
\text { Guillain- } \\
\text { Barré } \\
\text { Syndrome }\end{array}$ & 号. \\
\hline
\end{tabular}

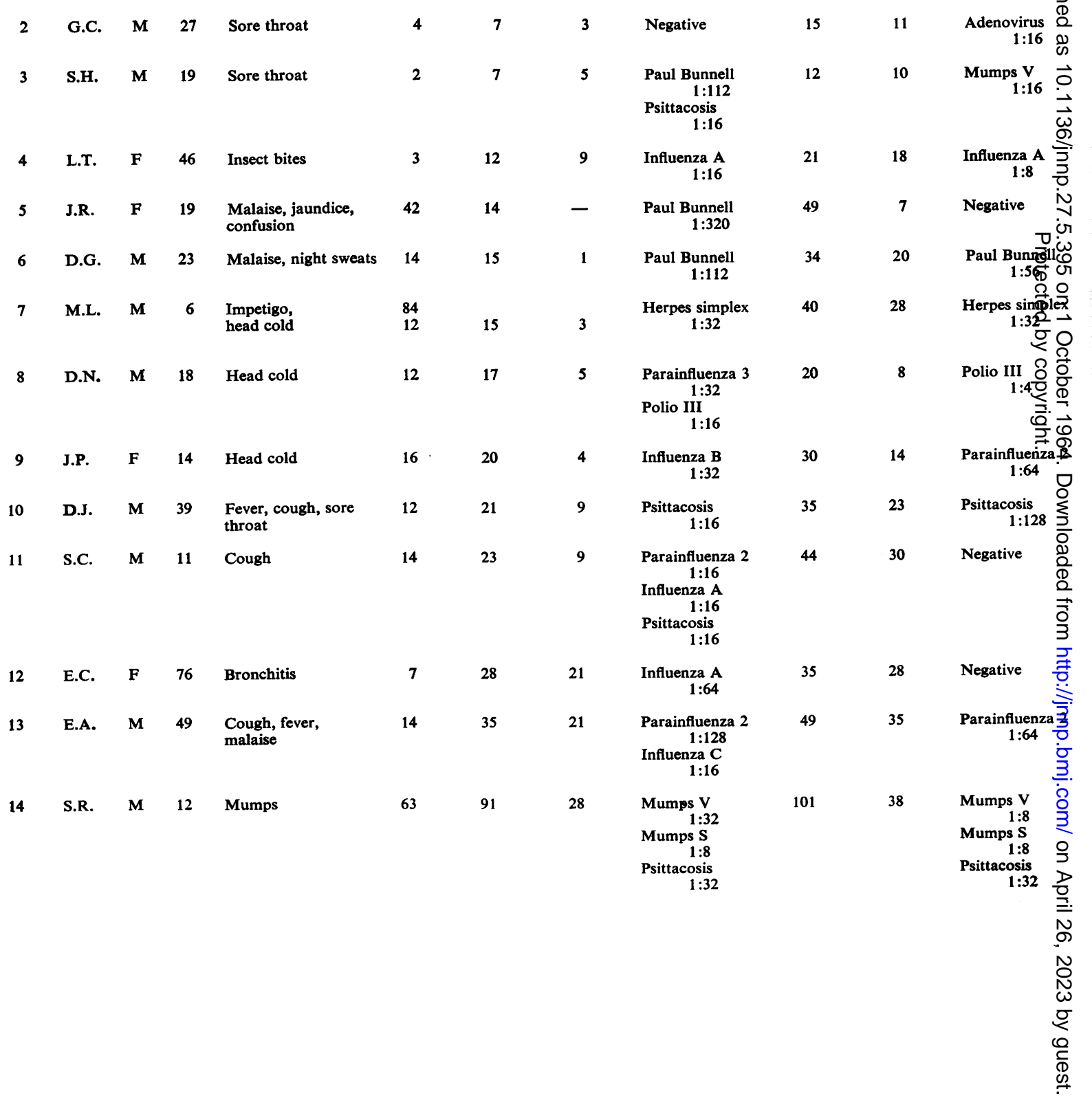


TABLE VIb-continued

SEROLOGICAL EVIDENCE (COMPLEMENT-FIXING ANTIBODIES) OF ANTECEDENT VIRUS INFECTION

IN GUILLAIN-BARRÉ SYNDROME IN 14 OF 29 CASES

Third Serum

Comments

\begin{tabular}{|c|c|c|}
\hline \multicolumn{2}{|c|}{ Interval (days) From } & \multirow{2}{*}{$\begin{array}{l}\text { Complement-fixing } \\
\text { Titre }\end{array}$} \\
\hline $\begin{array}{l}\text { Initial } \\
\text { Illness }\end{array}$ & $\begin{array}{l}\text { Onset of } \\
\text { Guillain- } \\
\text { Barré } \\
\text { Syndrome }\end{array}$ & \\
\hline
\end{tabular}

$-\quad-\quad-$

20

19

126

123

16

17

Adenovirus

$1: 8$

Negative

Influenza A

$1: 16$

28

16

Negative

70

58

Psittacosis

$1: 32$

108
$45 \quad \begin{array}{r}\text { Psittacosis } \\ 1: 32\end{array}$
1 Influenza $A$ or $B$ infection probable within previous three months: note titres are not falling 2 No complement-fixing tests; parainfluenza 2 and 3 and mumps $S$ titres may represent reaction with antigen common to parainfluenza 3, which may be cause of initial illness

Probable recent adenovirus infection

1 Initial illness was glandular fever

2 Past psittacosis infection

3 Mumps $V$ antibody a doubtfully significant finding

Influenza A (subclinical) infection probably within previous three months but note persistence of the circulating antibody

Initial illness was glandular fever

Initial illness was glandular fever

Probable 'flare up' of latent herpes by head cold

1 Initial illness was parainfluenza 3 infection

2 Significance of polio III antibody doubtful (immunization status not known)

Very recent parainfluenza 2 infection, influenza B infection within 3 months

1 Rising and falling titres strongly suggest recent psittacosis infection

2 Wife had similar respiratory illness and serological findings

1 Initial illness probably parainfluenza 2

2 Influenza A, probably within previous three months

3 Past psittacosis

Initial illness probably influenza $\mathbf{A}$ infection

1 Initial illness due to parainfluenza 2

2 Influenza $C$ infection probably within three months

1 Initial illness was mumps

2 Evidence of past psittacosis infection 
TABLE VIIb

SEROLOGICAL EVIDENCE OF (SUBCLINICAL) INTERCURRENT VIRUS INFECTIONS IN GUILLAIN-BARRÉ SYNDROME

\begin{tabular}{|c|c|c|c|c|c|c|c|c|}
\hline \multirow{3}{*}{$\begin{array}{l}\text { Case } \\
\text { No. }\end{array}$} & \multirow[t]{3}{*}{ Name } & \multirow[t]{3}{*}{ Sex } & \multirow{3}{*}{$\begin{array}{l}\text { Age } \\
(y r .)\end{array}$} & \multirow{3}{*}{$\begin{array}{l}\text { Nature of } \\
\text { Initial Illness }\end{array}$} & \multirow{3}{*}{$\begin{array}{l}\text { Latent } \\
\text { Period } \\
\text { (days) }\end{array}$} & \multicolumn{3}{|c|}{ First Serum } \\
\hline & & & & & & \multicolumn{2}{|c|}{ Interval (days) From } & \multirow{2}{*}{$\begin{array}{l}\text { Complement-fixing } \\
\text { Titre }\end{array}$} \\
\hline & & & & & & $\begin{array}{l}\text { Initial } \\
\text { Illness }\end{array}$ & $\begin{array}{l}\text { Onset of } \\
\text { Guillain- } \\
\text { Barré } \\
\text { Syndrome }\end{array}$ & \\
\hline
\end{tabular}

\begin{tabular}{lllllllll}
\hline 1 & K.C. & M & 35 & Cold, sore throat & 14 & 14 & 1 & Negative
\end{tabular}

$\begin{array}{lllllllll}2 & \text { G.M. } & \text { M } & 59 & \begin{array}{l}\text { Head cold, sore } \\ \text { throat }\end{array} & 1 & 3 & 2 & \text { See also Table VIa } \\ 3 & \text { J.P. } & \text { F } & 14 & \text { Head cold } & 16 & 20 & 4 & \text { See also Table VIa }\end{array}$

Second Serum

\begin{tabular}{|c|c|c|}
\hline \multicolumn{2}{|c|}{ Interval (days) From } & Complement-店king \\
\hline $\begin{array}{l}\text { Initial } \\
\text { Illness }\end{array}$ & $\begin{array}{l}\text { Onset of } \\
\text { Guillain- } \\
\text { Barré } \\
\text { Syndrome }\end{array}$ & $\stackrel{\text { N) }}{\stackrel{\infty}{\underline{\rho}}}$ \\
\hline
\end{tabular}

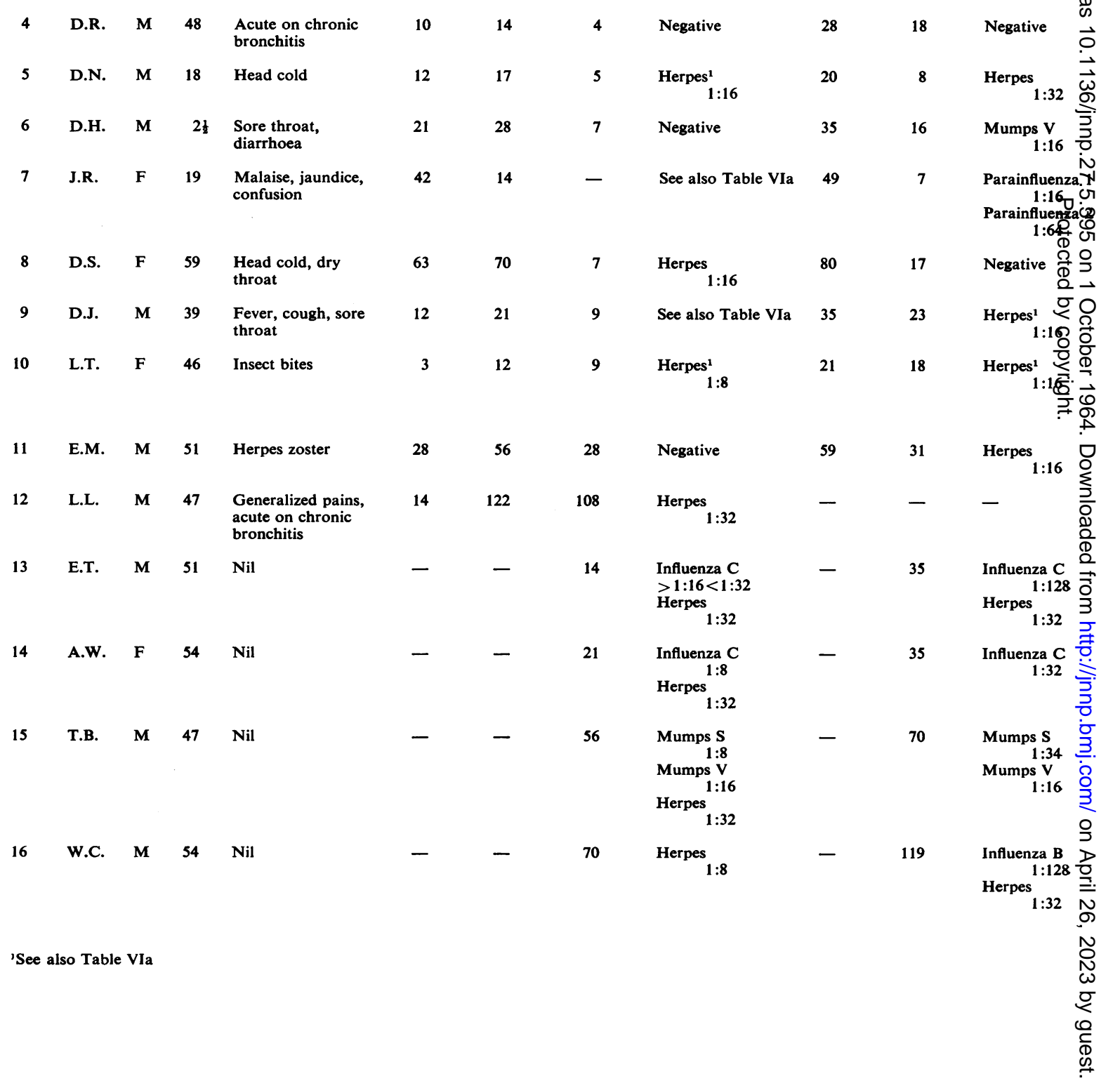


TABLE VIIb-continued

SEROLOGICAL EVIDENCE OF (SUBCLINICAL) INTERCURRENT VIRUS INFECTIONS IN GUILLAIN-BARRÉ SYNDROME

Third Serum

\begin{tabular}{lll}
\hline Interval (days) & From & Complement-fixing \\
\hline Initial & $\begin{array}{l}\text { Onset of } \\
\text { Illness }\end{array}$ & \\
& $\begin{array}{l}\text { Guillain- } \\
\text { Barré }\end{array}$ & \\
& Syndrome & \\
&
\end{tabular}

Comments

$49 \quad 36 \quad$ Herpes

$1: 16$

Influenza A

$1: 64$

28

16

Herpes

$1: 8$

63

21

Parainfluenza 2

$1: 64$

Probable stimulation of latent herpes infection

1 Also evidence (Table VI) of recent virus infections

2 Stimulation of latent herpes infection

1 Also evidence (Table VI) of antecedent parainfluenza and influenza infection

2 Probable stimulation of latent herpes infection

3 Significance of antibody to adenovirus unknown

Intercurrent influenza $\mathbf{A}$ infection

1 Stimulation of latent herpes

2 A fourth serum at 42 days-negative

Sera not tested for parainfluenza 2 or 3 . ? Cross-antigenicity of parainfluenza 2 or 3 with mumps antigen

1 Intercurrent parainfluenza 2 infection

2 First serum obtained before neurological illness

Stimulation of latent herpes infection

Probable stimulation of latent herpes infection

1 See also Table VI. ? Influenza C antibody related to influenza A antibody. Significance of polio I antibody doubtful

2 Stimulation of latent herpes infection

$1: 16$

1 Stimulation of latent herpes simplex infection

2 Fourth serum at 84 days-negative

Stimulation of latent herpes infection

1 Influenza $C$ infection

2 Stimulation of latent herpes infection

Herpes $1: 32$

$1: 16$

$63 \quad$ Negative

1 Influenza $C$ infection

2 Stimulation of latent herpes infection

$112 \quad$ Negative 1 Mumps infection

2 Stimulation of latent herpes infection

1 Influenza $B$ infection

2 Stimulation of latent herpes infection 
has been shown to occur at a time when this virus was prevalent among the general population at the same time. Information on virus prevalence in the population is lacking from the earlier reports referred to above, but we feel that at least in our cases the presence of these viruses is purely coincidental.

The epidemiological aspects of the present investigation have failed to show evidence that contacts of patients with the Guillain-Barré syndrome develop the same condition, although Saint (1951) reported a rare occurrence in which two Australian aborigines (brother and sister) developed the syndrome within three months of each other. The evidence presented by Campbell (1958) that six of a series of 12 patients with the Guillain-Barré syndrome had been in recent contact with cats thought to be suffering from feline enteritis is certainly suggestive of an epidemiological relationship between the animal and human diseases, but as no such association was noted in our larger series its aetiological importance appears limited. Furthermore, our attempts to isolate a virus in kitten kidney tissue culture, a system susceptible to feline enteritis virus, have been unsuccessful.

Serological studies in the present series of cases have similarly failed to reveal evidence of circulating antibodies to any one particular virus.

Our observation that the Guillain-Barré syndrome occurs mainly in the first half of the year contrasts with that of Mulroy (1954), who found a uniform distribution of cases throughout the year, but is in full agreement with Marshall (1963). The significance of this curious time incidence is unknown.

SIGNIFICANCE OF ANTECEDENT INFECTIONS The occurrence of a very wide variety of such illnesses in close temporal relationship to the Guillain-Barré syndrome has, of course, been frequently reported in the literature. Our clinical findings confirm this, for a large proportion (36/52 cases) had some antecedent infection and further support is obtained from the high incidence ( $48 \%$ ) of miscellaneous virus infections encountered serologically. Of such infections as occurred in the present series (Table III), however, particular attention has been given in the literature to the occurrence of respiratory tract infections as prodromal illnesses both in central (Greenfield, 1930) as well as in peripheral nervous demyelinating diseases. The controlled epidemiological study and the serological results reported here suggest that there is a significant correlation between the respiratory infections occurring within one month of the Guillain-Barré syndrome, but there is no such correlation if the latent period is extended to three months.

The possibility that antecedent influenzal infection was an aetiological factor in acute demyelinating disease was discussed by Greenfield (1930) in cō̄nexion with two cases of acute disseminated epcephalomyelitis. However, he made it quite cleyr that his use of the term 'influenza' was based solely on clinical grounds. Similarly, Leigh (1946), whio reported five cases of the Guillain-Barré syndromze after 'influenza', based this diagnosis solely on the occurrence of respiratory tract infection during influenza B epidemic and there was no supportiog virological evidence. Wells, James, and Evans (1959), however, reported two fatal cases of the Guillai Barré syndrome with virological evidence of recegt influenza A infection, but were extremely cautiogs in their interpretation of this finding and did n⿳亠口冋t dogmatically claim an aetiological relationsh between the influenzal illnesses and the neurological syndrome. Similar caution was urged by Flewett arfa Hoult (1958) in their account of post-influenza encephalitis, and in fact the results of the present study failed to show any significant correlatiof between influenza and the Guillain-Barré syndrome: As further evidence against such an association, two recent winter outbreaks of true influenza in the weis Midlands merit attention. The first (1960-61) was widespread epidemic due to influenza A2 (Hearn, 1963); the second (1961-62), due to fluenza B, was of more limited extent and sevefits During these outbreaks the incidence of the GuillainBarré syndrome was not particularly high in experience, and proportionally the largest number $f$ cases occurred from November 1959 to Oct 1960, when the prevalence of influenza was comperaztively low. It can therefore be concluded that in 1 th series the incidence of true antecedent influenzat infection shows no statistically significant correlp tion with the Guillain-Barré syndrome, but while th: would appear to imply that the occurrence of suct an infection is purely coincidental, we do not clainf to have entirely excluded an aetiological role fo influenza in some cases of this condition.

Glandular fever was particularly noted in relation to the Guillain-Barré syndrome by Peters, Widerman, Blumberg, and Ricker (1947) and by man subsequent observers; its previous occurrence i three of our patients reinforces the belief that it ma be aetiologically significant.

The relationship of infection by the psittacos: group of organisms with the Guillain-Barré syno drome, apparently a significant one in our series, has hitherto not been generally recognized and we have only traced one report mentioning psittacosis as an associated illness (Michon, Larcan, Huriet, and Thiriet, 1960).

Chickenpox is another well known, if less frequento prodromal illness (e.g., Welch, 1962), and case findings are doubtful, for the majority of these cases 
occurring after herpes zoster are even more rare, but three further cases of the Guillain-Barré syndrome following herpes zoster infection have recently been reported by Knox et al. (1961) who also reviewed the literature on this subject.

The neurological complications of the 'specific fevers' commonly encountered in this country have been extensively reviewed by Miller, Stanton, and Gibbons (1956) and by Miller (1956). These infections include mumps and chickenpox (examples of which are included in Table III), as well as measles and scarlet fever. From their survey of the literature they found that, with the exception of scarlet fever, the latent period between the initial febrile illness and the Guillain-Barré syndrome was never longer than 24 days. The latent periods for the specific infectious diseases in our series of patients (with the notable exception of respiratory infections) varied more widely (Table III), and we feel that this makes their significance more questionable, a view supported by Tyler (1957), for measles in particular. A similar variability in the latent period (two days to seven and a half weeks) was reported by Raftery, Schumacher, Grain, and Quinn (1954) for cases of the Guillain-Barré syndrome following glandular fever and by Knox et al. (1961) for cases occurring after herpes zoster.

Winkelman (1949) has given an excellent account of the Guillain-Barré syndrome following smallpox vaccination and the latent periods of his cases were reasonably constant (seven to 14 days). The latent period in our case, however, was only four days (D.P., Table III), and, as he had also had an upper respiratory tract infection two days earlier, the significance of his vaccination, even though it resulted in a moderately severe local reaction, must remain doubtful. In addition, of the 52 patients he was the only case in which there was any close time relationship with an immunization programme (either active or passive), and therefore from the statistical point of view it would seem reasonable to conclude that prophylactic immunization is of limited aetiological significance as an antecedent factor in the GuillainBarré syndrome, despite the comparatively large number of case reports of such an association.

The relevance of the other antecedent incidents referred to in Table III is as yet unknown, for insect bites and impetigo do not appear to have been reported previously. Similarly, no specific mention has been made of the Guillain-Barré syndrome following non-neurological operations, such as occurred in one of our patients (G.H.) who developed the Guillain-Barré syndrome 10 days after prostatectomy. One of the two post-influenzal cases reported by Wells et al. (1959), however, had nine days previously sustained a fracture of the mandible which was treated by open operative reduction some four days later, but no significance was apparently attached to this episode. Finally, the absence of a known cause for the fever and malaise in one case (C.D.) and for the rash in another (S.M.) of the subjects listed in Table III makes the relevance of these antecedent illnesses doubtful.

In summary, therefore, it seems highly improbable that one single aetiology will explain all cases of the Guillain-Barré syndrome, but our evidence supports the concept of the importance of antecedent infections, although the mechanism of their action is obscure. A tempting explanation is one that relates the two illnesses in a similar way to the hypothesis relating $\beta$-haemolytic streptococcal throat infections with rheumatic fever and acute nephritis (reviewed by Cruickshank, 1963). Evidence is available (Waksman and Adams, 1955; Melnick, 1963) that, in some cases at least, autoimmune processes might be involved in the aetiology of the Guillain-Barré syndrome. It is therefore possible that antecedent infections, such as those discussed above, similarly initiate these immunological disturbances, although other possible mechanisms, such as the activation of a latent virus postulated by Robbins (1959), cannot be excluded.

There are, however, some important differences from acute nephritis and rheumatic fever. Thus no single viral analogue to the streptococcus has been identified, and the latent period for non-respiratory antecedent infections is exceedingly variable. In addition, a parallel study has been made of the role of virus infections in the initiation of certain autoimmune disturbances. This study (Melnick, to be published) was made with particular reference to the occurrence of auto-immune complement-fixing tissue antibodies (Gajdusek, 1958), and it revealed that mumps infection was the only one associated with an especially high subsequent incidence of such antibodies. None of the other virus infections serologically studied, which, including true influenza, have also been studied in this series (Table VI), showed such an association.

INTERCURRENT INFECTIONS One important reason for giving particular attention to such infections during the acute and recovery phases of the GuillainBarré syndrome was the observation by Miller (1961) that signs of a specific generalized infection may develop after the onset of acute haemorrhagic encephalomyelitis, a condition also widely believed to be related to antecedent infections. This was not observed clinically in the present series of patients, but there was an appreciable incidence of serologically proven, i.e., subclinical, virus infections (Table VII). The significance to be attached to these 
showed evidence only of herpes simplex infection which could well have been triggered off in a nonspecific way by antecedent infection or the neuropathy itself. Moreover, these subclinical virus infections had no adverse clinical effects on the neurological condition.

In conclusion, aetiological relationships have been suggested between respiratory infections and a variety of other clinical conditions. including acute central nervous demyelinating disease (Greenfield, 1930), thrombocytopenic purpura (Ackroyd, 1949; Wintrobe, 1961), haemolytic anaemia (reviewed by Britton, 1963), and even certain cases of Hashimoto's disease, 'auto - immune thyroiditis' (Roitt and Doniach, 1960). These reports, however, gave no information about the frequency of association of respiratory infections with these diseases, as compared with a control population.

\section{SUMMARY}

An epidemiological and virological study of 52 cases of the Guillain-Barré syndrome has failed to provide evidence to support the theory that one specific virus is the cause of this condition.

It was observed to occur more frequently in the first half of the year, particularly in the months of February and June.

A controlled trial has confirmed the clinical impression that antecedent virus infections occur commonly. There was a particularly high incidence of upper respiratory tract infections within one month of the onset of this neurological illness. True influenza, however, was an uncommon cause of such infections.

The association of certain other infective and noninfective antecedent conditions with this syndrome is reported for the first time. The aetiological role of these antecedent illnesses is discussed.

This work was done during the tenure by one of us (S.C.M.) of the Jeff Hall Fellowship endowed by the National Fund for Poliomyelitis and Other Crippling Diseases, to which we are grateful for financial support. We also wish to thank Mrs. B. A. M. Harvey and Mr. J. R. Foster for their technical assistance and Miss P. Kelly for her invaluable secretarial help. Thanks are also due to Dr. J. A. H. Waterhouse (Department of Medical Statistics) for his advice. Our gratitude also goes to the numerous consultant physicians and surgeons of the United Birmingham Hospitals and the Birmingham Regional Hospital Board, who allowed us unlimited access to their patients.

\section{REFERENCES}

Ackroyd, J. F. (1949). Three cases of thrombocytopenic purpura occurring after rubella. Quart. J. Med., 18, 299-318.

Bergamasco, A., and Longhi, A. (1949). Sull inoculazione nel topino bianco degli ultravirus cultivati del .... e della radicoloneurite di Guillain-Barre. Arch. ital. Dermat., 22, 241-258.
Britton, C. J. C. (1963). In Whitby and Britton's Disorders of the Blood, 9th ed., pp. 337-338. Churchill, London.

Campbell, A. M. G. (1958). The aetiology of polyneuritis. Proc. ro Soc. Med., 51, 157-159.

Cruickshank, B. (1963). In Clinical Aspects of Immunology, edited P. H. G. Gell, and R. R. A. Coombs, pp. 572-592. Blackwe Oxford.

Flewett, T. H. (1963). The laboratory diagnosis of influenza. Postgrad med. J., 39, 586-590. influenzal encephalitis. Lancet, 2, 11-15.

Furtado, D. (1950). Pathogénie du syndrome de Guillain-Barn Mschr. Psychiat. Neurol., 119, 264-273.

Gajdusek, D. C. (1958). An "auto-immune" reaction against human tissue antigens in certain acute and chronic diseases. Arct intern. Med., 101, 9-29.

Gear, J., Measroch, V., and Prinsloo, F. R. (1956). The medical and public health importance of the Coxsackie viruses. $S$. Afr. met J., 30, 806-810.

Greenfield J. G. (1930). Acute disseminated encephalomyelitis as $\overline{\bar{A}}$ sequel to "Influenza". J. Path. Bact., 33, 453-462.

Grist, N. R., Kerr, J., and Isaacs, B. (1961). Rapid serological dia® nosis of an outbreak of influenza. Brit. med.J., 2, 431.

Guillain, G. (1953). Considérations sur le syndrome de Guillain Barré. Ann. Med., 54, 81-149.

—, Barre, J. A., and Strohl, A. (1916). Sur un syndrome de Radiculo-nevrite avec hyperalbuminose. Bull. Soc. med. Hop (Paris), 40, 1462-1470.

Haymaker, W., and Kernohan, J. W. (1949). The Landry-Guillaip Barré syndrome. Medicine (Baltimore), 28, 59-141.

Hearn, G. W. (1963). Influenza in hospital 1960-61. Postgrad. med. $\vec{p}$ 39, 567-573.

Jackson, A. L. (1961). A clinical study of the Landry-Guillain-Barte syndrome with reference to aetiology, including the role of Coxsackie virus infections, S. Afr. J. Lab. clin. Med., 7, 121 $23 \mathrm{C}_{0}$

Knox, J. D. E., Levy, R., and Simpson, J. A. (1961). Herpes zosteø and the Landry-Guillain-Barré syndrome, J. Neurol. Neturgo surg. Psychiat., 24, 167-172.

Lassen, H. C. A., Ipsen, J., and Bang, J. (1943). Etiological studi on acute polyradiculitis (radiculo-meningo-myelitis) of the Lamfiry type. Acta med. scand., 115, 139-150.

Leschke, E. (1914). Uber den Erreger der Landry'schen Parąyse. Klin. Wschr., 51, 783-785.

Leigh, A. D. (1946). Infections of the nervous system occurring de an epidemic of influenza B. Brit. med. J., 2, 936-938.

Marshall, J. (1963). The Landry-Guillain-Barré syndrome. Pargo 86, 55-66.

Melnick, S. C. (1963). Thirty-eight cases of the Guillain-Barre syntdrome: an immunological study. Brit. med. J., 1, 368-373.

Michon, P., Larcan, A., Huriet, C., and Thiriet, M. (1960). Anure and fatal polyradiculoneuritis with albumino-cytologica dissociation during and after serologically confirmed influenze? Bull. Soc. med. Hôp. (Paris), 76, 703-706.

Miller, H. (1956). Discussion on the neurological complications of the acute specific fevers. Proc. roy. Soc. Med., 49, 139-146. (1961). In Scientific Aspects of Neurology, edited by H. Garland p. 222. Livingstone, Edinburgh and London.

-, Stanton, J. B., and Gibbons, J. L. (1956). Parainfectious encephalomyelitis and related syndromes. Quart. J. Med.., 25, 427-505.

Mulroy, R. D. (1954). Guillain-Barré syndrome. N.Y. St. J. Med̆ 54, $1761-1764$.

Osler, L. D., and Sidell, A. D. (1960). The Guillain-Barré syndromer New Engl. J. Med., 262, 964-969.

Pappenheimer, A. M., Bailey, O. T., Cheever, F. S., and Daniels, J. B. (1951). Experimental polyradiculitis in monkeys. J. Neuropat clin. Neurol., 1, 48-62.

Parker, W., Wilt, J. C., Dawson, J. W., and Stackiw, W. (1960் Landry-Guillain-Barre syndrome-the isolation of an Eche virus type 6. Canad. med. Ass. J., 82, 813-815.

Peters, C. H., Widerman, A., Blumberg, A., and Ricker, W. A. (1947 Neurologic manifestations of infectious mononucleosis. Arch. intern. Med., 80, 366-373.

Raftery, M., Schumacher, E. E., Grain, G. O., and Quinn, E. L. (1954 Infectious mononucleosis and Guillain-Barré syndrome. Ibid.; 93, 246-253.

Robbins, F. C. (1959). In “Allergic” Encephalomyelitis. A symposiun? edited by M. W. Kies and E. C. Alvord, p. 474. Thomass? Springfield, Illinois. 
Roitt, 1. M., and Doniach, D. (1960). Thyroid auto-immunity. Brit. med. Bull., 16, 152-158.

Saint, E. G. (1951). The Guillain-Barré syndrome: three cases in aboriginal natives. Med. J. Aust., 2, 50-52.

Stuart-Harris, C. H. (1953). Influenza and Other Virus Infections of the Respiratory Tract. Arnold, London.

Tyler, H. R. (1957). Neurological complications of rubeola (measles). Medicine (Baltimore), 36, 147-167.

Waksman, B. H., and Adams, R. D. (1955). Allergic neuritis: experimental disease of rabbits induced by injection of peripheral nervous tissue and adjuvants. J. exp. Med., 102, 213-236.
Welch, R. G. (1962). Chicken-pox and the Guillain-Barré syndrome. Arch. Dis. Childh., 37, 557-559.

Wells, C. E. C., James, W. R. L., and Evans, A. D. (1959). GuillainBarré syndrome and virus of influenza A (Asian strain). Arch. Neurol. Psychiat. (Chic.), 81, 699-705.

Winkelman, N. W., Jr. (1949). Peripheral nerve and root disturbances following vaccination against smallpox. Arch. Neurol. Psychiat. (Chic.), 62, 421-438.

Wintrobe, M. M. (1961). Clinical Hematology, 5th ed., p. 821. Kimpton, London. 